\author{
Grzegorz Gogowski \\ Uniwersytet Warszawski \\ Grupa Brytyjskich Studiów Społeczno-Politycznych BRITANNIA \\ grzegorzgogowski@gmail.com
}

\title{
Dylematy polityki obronnej Wielkiej Brytanii po wyborach parlamentarnych 2010
}

\begin{abstract}
Streszczenie: Utworzony po wyborach parlamentarnych w Wielkiej Brytanii w maju 2010 roku koalicyjny rząd Dawida Camerona stanął w obliczu konieczności rozwiązania poważnych dylematów w zakresie polityki zbrojeniowej. Największym wyzwaniem była redukcja ogromnego deficytu budżetowego pozostawionego $\mathrm{w}$ ministerstwie obrony przez Partię Pracy, przy jednoczesnym zachowaniu wysokiego poziomu zdolności wojskowych. Głównym zadaniem postawionym przed artykułem, jest przeprowadzenie analizy działań podjętych przez brytyjskie władze na przestrzeni ostatnich 3 lat, ukierunkowanych na osiągnięcie obu wspomnianych celów. W tym celu omówiono najważniejsze decyzje jakie brytyjskie władze podjęły by ograniczyć wydatki obronne. Przedstawiono również stopniowo zarysowujący się kształt, jaki zostanie nadany brytyjskim siłom zbrojnym w przyszłości. Szczególny dużo uwagi poświęcono dokonaniu pogłębionej analizy najpoważniejszych inwestycji zbrojeniowych przeprowadzanych obecnie oraz w przyszłości przez Zjednoczone Królestwo. Poszczególne inwestycje omówiono pod kątem ich potencjalnej przydatności dla brytyjskich sił zbrojnych, kosztów ich finalizacji, a także czynników które wpływały na decyzje o wyborze konkretnego wariantu uzbrojenia. W ostatniej części artykułu scharakteryzowano dylematy przed jakimi stanęły władze w zakresie przyszłości brytyjskiej broni jądrowej.
\end{abstract}

Już na początku swojej kadencji, konserwatywno-liberalny gabinet Davida Camerona stanął w obliczu poważnych wyzwań w zakresie polityki obronnej. Po pierwsze, należało ujednolicić podejście do polityki obronnej i przystosować je do współczesnych uwarunkowań międzynarodowych i najpoważniejszych zagrożeń. Po drugie, trzeba było określić kierunki przyszłego rozwoju brytyjskich sił zbrojnych, co wiązało się z koniecznością wyboru priorytetów zbrojeniowych na kolejne lata. Po trzecie, należało 
przeanalizować możliwe scenariusze dotyczące przyszłości brytyjskich środków odstraszania jądrowego (tzw. „nuclear deterrent”). Podczas realizacji wszystkich spośród wymienionych priorytetów, nowe brytyjskie władze miały być poważnie ograniczone przez efekty kryzysu gospodarczego, dodatkowo potęgujące problemy finansowe, z którymi przez kilka poprzednich lat borykały się brytyjskie siły zbrojne. Wkrótce po wyborach parlamentarnych z 2010 roku, oszacowano, że "czarna dziura budżetowa” ministerstwa obrony pod rządami Partii Pracy sięgnęła 38 miliardów funtów, co oznaczało, że była ona większa niż roczny budżet obronny Zjednoczonego Królestwa (Chalmers, 2011: 3). Dlatego też, podczas podejmowania wszystkich decyzji z zakresu polityki obronnej, nowy gabinet musiał uwzględniać naglącą potrzebę ograniczania wydatków budżetu obronnego. Zadanie, przed jakim stanął gabinet Davida Camerona było więc podwójnie utrudnione - należało zmniejszyć deficyt budżetu obronnego przy jednoczesnym utrzymaniu zdolności wojskowych na odpowiednio wysokim poziomie. Realizacji wskazanych powyżej priorytetów miał służyć całościowy przegląd polityki obronnej rozpoczęty tuż po wyborach, którego wyniki miały zostać opublikowane na jesieni 2010 roku, w pierwszym od dwunastu lat dokumencie całościowo obejmującym brytyjską politykę bezpieczeństwa.

Głównym celem postawionym przed poniższym artykułem jest próba szczegółowej analizy głównych dylematów, przed jakimi stanął koalicyjny gabinet Davida Camerona w zakresie polityki militarnej. Analizie poddane będą wyłącznie problemy należące do wymiaru wewnętrznego brytyjskiej polityki obronnej, pominięty zostanie natomiast szerszy kontekst międzynarodowy. Szczególny nacisk zostanie położony na zagadnienia związane $\mathrm{z}$ auto-postrzeganiem Wielkiej Brytanii w środowisku międzynarodowym, a także na najważniejsze spośród dylematów zbrojeniowych przed jakimi stanęły władze Zjednoczonego Królestwa na przestrzeni ostatnich trzech lat.

\section{Rola Wielkiej Brytanii w systemie bezpieczeństwa międzynarodowego}

Choć w okresie zimnej wojny Wielka Brytania utraciła ostatecznie status mocarstwa światowego, udało się jej zdobyć i zachować dwa atrybuty mocarstwowości: stałe miejsce w Radzie Bezpieczeństwa Organizacji Narodów Zjednoczonych oraz dostęp do broni jądrowej. Szczególnie formalny wyznacznik mocarstwowości warunkuje autopercepcję Zjednoczonego Królestwa w systemie międzynarodowym. Status permanentnego członka Rady Bezpieczeństwa ONZ jest fundamentem poczucia zwiększonej odpowiedzialności za utrzymanie pokoju i bezpieczeństwa międzynarodowego, które stało się jednym z tradycyjnych założeń brytyjskiej polityki bezpie- 
czeństwa (Gołembski, 2001: 62). Zakończenie zimnej wojny nie spowodowało zmiany dotychczasowej postawy Brytyjczyków, którzy zachowali swoistą „psychologiczną gotowość” do przejęcia odpowiedzialności za bezpieczeństwo również poza obszarem wyznaczonym przez Traktat Północnoatlantycki (Wiśniewski 2008: 87). Taka postawa będąca niewątpliwie osobliwym reliktem ery imperialnej stała się elementem politycznej tradycji brytyjskiej, o czym świadczy chociażby zasadnicza zgodność obu głównych partii brytyjskich w odniesieniu do tej kwestii. Np. w opublikowanym w 1998 roku przez laburzystowski rząd Strategicznym Przeglaqdzie Obrony zapisano, że Wielka Brytania jest gotowa by pełnić w polityce międzynarodowej rolę "siły na rzecz dobra” (force for good) (Strategic Defence Review, 1998: 11) . Głównym architektem takiej postawy brytyjskiej był bez wątpienia premier Tony Blair. Przejęcie większej odpowiedzialności za bezpieczeństwo narodowe znakomicie wpisywało się bowiem w blairowską „Doktrynę Międzynarodowej Wspólnoty”, przedstawioną 24 kwietnia 1999 roku w Chicago, dopuszczającą m.in. interwencję zbrojną społeczności międzynarodowej w innym państwie w celu ochrony i promocji praw człowieka, nawet jeśli ONZ nie autoryzowała takiej akcji (Blair, 2011: 351). Przekonania Tony'ego Blaira wciągnęły jednak Wielką Brytanię w cztery konflikty zbrojne, z czego przynajmniej dwa (Wojna w Kosowie oraz II Wojna w Iraku) wzbudzały duże kontrowersje ze względu na sprzeczność z zasadami prawa międzynarodowego. Zwłaszcza decyzja o wysłaniu wojsk do Iraku spotkała się ze zmasowaną krytyką: podczas demonstracji w Londynie przeciwko włączeniu się do konfliktu protestowało ponad milion ludzi, doszło również do największej od ponad stu lat partyjnej rewolty, kiedy podczas głosowania w dniu 26 lutego 2003 roku 120 posłów Partii Pracy sprzeciwiło się udzieleniu wsparcia Stanom Zjednoczonym (Warchał, 2010: 187). Negatywna ocena zaangażowania w wojnę w Iraku, a także „zmęczenie” związane z bardzo kosztowną i przedłużającą się operacją w Afganistanie stały się przyczynami wzrastającej niechęci brytyjskiego społeczeństwa wobec angażowania się Wielkiej Brytanii w regionach oddalonych od własnego terytorium (Seldon, 2007: 632).

Kiedy więc gabinet Davida Camerona stanął przed koniecznością określenia stopnia aktywności Zjednoczonego Królestwa na arenie międzynarodowej, dwie kwestie znacząco zawężały jego pole manewru. Po pierwsze, w dobie kryzysu gospodarczego, to czynniki ekonomiczne miały być kluczową determinantą gotowości Wielkiej Brytanii do działania na arenie międzynarodowej. Po drugie, brytyjska opinia publiczna domagała się ścisłego sprzężenia przyszłych decyzji o ewentualnym rozmieszczeniu wojsk z dala od własnego terytorium, z faktycznym zagrożeniem interesów Zjednoczonego Królestwa. W efekcie, w zapisach Strategicznego Przeglądu 
Obrony i Bezpieczeństwa (SDSR) koalicyjny rząd brytyjski wyraźnie zdystansował się od polityki prowadzonej w okresie sprawowania władzy przez Partię Pracy. W dokumencie podkreślono gotowość do użycia sił zbrojnych poza granicami kraju, w sytuacji, w której w sposób jednoznaczny zagrożone są interesy Zjednoczonego Królestwa. Warto jednak zaznaczyć, że zapowiedziano bardziej selektywną postawę w odniesieniu do rozmieszczenia sił zbrojnych, a ewentualna interwencja militarna zostanie przeprowadzona jeśli będzie ona zgodna z prawem międzynarodowym, możliwe będzie precyzyjne określenie celu końcowego i strategii wyjścia, a potencjalne korzyści będą proporcjonalne w stosunku do kosztów ekonomicznych, politycznych i ludzkich (SDSR, 2010: 17) ${ }^{1}$. Wszystkie wspomniane warunki są bez wątpienia efektem negatywnych doświadczeń płynących z misji w Afganistanie, która obecnie wydaje się być dla Brytyjczyków swoistym „wzorem” nieudanej operacji. Krytyczna ocena operacji ISAF wynika przede wszystkim z nierealności zakończenia jej sukcesem, a także rosnącej liczby poległych na afgańskim gruncie brytyjskich żołnierzy (przekraczającej obecnie czterystu poległych). Należy również pamiętać o ogromnym obciążeniu finansowym budżetu obronnego wynikającym z obecności w Afganistanie kontyngentu brytyjskiego, która pochłania około 10\% wszystkich wydatków obronnych Zjednoczonego Królestwa (SIPRI Yearbook, 2010: 193-195).

Pomimo ogromnych kosztów i negatywnych doświadczeń płynących z misji ISAF, Wielka Brytania wciąż jest gotowa by ponosić zwiększoną odpowiedzialność za bezpieczeństwo międzynarodowe. Przejawem takiej gotowości była wojna w Libii w 2011 roku, kiedy wobec niechęci Stanów Zjednoczonych do zaangażowania się w rozwiązanie tego problemu, Wielka Brytania wraz z Francją stanęły na czele międzynarodowej koalicji mającej na celu odsunięcie od władzy reżim pułkownika Mauammara Kaddafiego. Warto podkreślić, że konflikt libijski dostarczył dwóch dowodów, będących potwierdzeniem dużego potencjału wojskowo-politycznego Zjednoczonego Królestwa. Po pierwsze, powietrzno-morska Operacja Ellamy dowiodła, że Wielka Brytania jest nadal zdolna do przeprowadzenia natychmiastowej i skutecznej interwencji wojskowej nawet w regionie stosunkowo odległym od własnego terytorium. Po drugie, władze brytyjskie będące wraz z Francją najbardziej zagorzałymi zwolennikami wprowadzenia strefy zakazu lotów nad Libią, dzięki swoim staraniom na arenie dyplomatycznej były

1 Ze względu na obszerny tytuł oryginalny dokumentu Securing Britain in an Age of Uncertainty: The Strategic Defence and Security Review autor zdecydował o wykorzystaniu skrótu „SDSR” używanego w publicystyce anglojęzycznej podczas tworzenia odwołań do wspomnianej publikacji. 
w stanie zdobyć międzynarodowe poparcie dla swojego projektu i doprowadzić do uchwalenia przez Radę Bezpieczeństwa Organizacji Narodów Zjednoczonych Rezolucji nr 1973 będącej podstawą prawną późniejszej interwencji. W ten sposób Wielka Brytania dowiodła, że nadal potrafi odegrać rolę lidera społeczności międzynarodowej na płaszczyźnie dyplomatyczno-militarnej, jeśli sytuacja tego wymaga.

Drugą z sytuacji, która wydaje się istotna z punktu widzenia obecnej i przyszłej roli Wielkiej Brytanii w systemie bezpieczeństwa międzynarodowego jest wojna domowa w Mali, jaka wybuchła na początku 2013 roku. Podczas tego konfliktu, Wielka Brytania udzieliła wsparcia logistycznego (m.in. poprzez udostępnienie samolotów transportowych C-17 Globemaster III) Francji, która przejęła na siebie całość odpowiedzialności za rozwiązanie problemu islamskich rebeliantów okupujących północną część Mali. Rząd brytyjski zdecydował także o wysłaniu do państw Afryki Zachodniej personelu wojskowego, którego głównym zadaniem będzie szkolenie miejscowych służb bezpieczeństwa $\mathrm{w}$ zakresie zwalczania terroryzmu. Szczególnie istotnym wydaje się zastrzeżenie premiera Davida Camerona, że brytyjscy żołnierze podczas swojego pobytu w Mali w żadnym wypadku nie będą uczestniczyli w działaniach wojennych (Codner, 2013). Patrząc przez pryzmat wcześniejszego konfliktu libijskiego, a także wspomnianych powyżej doświadczeń związanych z wojnami w Afganistanie i Iraku można zatem zaryzykować tezę, że Zjednoczone Królestwo w najbliższej przyszłości będzie najprawdopodobniej bardzo sceptyczne wobec ewentualnego rozmieszczenia własnych sił lądowych $\mathrm{w}$ regionach objętych walkami. Niejako potwierdzeniem takiego przypuszczenia jest wypowiedź brytyjskiego ministra obrony Philipa Hammonda, który podczas swojego wystąpienia w Izbie Gmin oznajmił, że brytyjska postawa wobec kryzysu w Mali powinna stanowić modelowe rozwiązanie wykorzystywane w przyszłości. Hammond podkreślił, że w przypadku zagrożeń związanych z państwami upadłymi Wielka Brytania zamiast wysyłać do walki własne oddziały lądowe, powinna skupić się na pomocy miejscowym rządom w rozwiązywaniu ich problemów wewnętrznych (Norton-Taylor, 2013).

Wydaje się, że przytoczoną powyżej wypowiedź ministra Hammonda można interpretować dwojako. Być może jest to zapowiedź bardziej powściągliwej postawy Wielkiej Brytanii w odniesieniu do przyszłych międzynarodowych operacji pokojowych. Patrząc przez pryzmat niedawnej wojny w Libii bardziej prawdopodobnym wydaje się jednak scenariusz, w którym Brytyjczycy będą nadal selektywnie angażować się $\mathrm{w}$ takie interwencje z wyraźną preferencją przyznawaną działaniom powietrzno-morskim. Taki scenariusz wydaje się tym bardziej prawdopodobny jeśli wziąć pod uwagę plany zakładające nadanie brytyjskim siłom zbrojnym w najbliższych latach wyraźnie ekspedycyjnego charakteru. 


\section{Główne dylematy zbrojeniowe Zjednoczonego Królestwa}

Po przejęciu władzy, konserwatywno-liberalny rząd Davida Camerona stanął przed koniecznością przeprowadzenia drastycznych cięć w budżecie ministerstwa obrony przy jednoczesnym utrzymaniu zdolności wojskowych na możliwie wysokim poziomie. Osiągnięcie tych wzajemnie wykluczających się celów wymagało od nowych władz brytyjskich podjęcia szeregu niezwykle istotnych i niekiedy bardzo dotkliwych decyzji, które miały zostać opublikowane w Strategicznym Przeglądzie Obrony i Bezpieczeństwa.

Podstawowym wyzwaniem stojącym przed rządem było określenie skali cięć które zostaną przeprowadzone w najbliższych latach w budżecie ministerstwa obrony. Większość brytyjskich ekspertów i publicystów przewidywało, że w ciągu kilku lat budżet obronny zostanie zmniejszony o ok. 10-15\%, najbardziej skrajne analizy zapowiadały aż dwudziestopięcioprocentowe cięcia, co jednak wydawało się nierealne ze względu na nadal duże potrzeby obronne Zjednoczonego Królestwa (Chalmers, 2010: 9). Warto zaznaczyć, że znajdujący się w trudnym położeniu rząd brytyjski znalazł się pod dodatkową presją, kiedy niedługo przed publikacją efektów przeglądu obronnego amerykańska sekretarz stanu Hilary Clinton wyraziła zaniepokojenie przewidywanymi cięciami budżetu, podkreślając, że mogłyby one wpłynąć negatywnie na wkład Wielkiej Brytanii w tworzenie potencjału militarnego Sojuszu Północnoatlantyckiego (Kirkup, 2010). Realizacji głównego priorytetu, jakim było obniżenie wydatków obronnych Zjednoczonego Królestwa musiały towarzyszyć szczegółowe decyzje dotyczące przyszłości kluczowych obszarów brytyjskich zdolności wojskowych. Zagadnieniami, wymagającymi uregulowania były w szczególności: przyszły stan liczbowy armii, główny kierunek rozwoju sił zbrojnych, wycofanie części z używanego dotychczas sprzętu, redukcja niektórych z planowanych zakupów uzbrojenia, a także przyszłość brytyjskiego odstraszania jądrowego (Military Balance 2012, 2012: 81-87).

\section{Konieczność poszukiwania oszczędności}

Efekty trwającej kilka miesięcy gruntownej analizy brytyjskiej polityki bezpieczeństwa zostały oficjalnie przedstawione w październiku 2010 roku w długo oczekiwanym Strategicznym Przeglądzie Obrony i Bezpieczeństwa (SDSR) oraz towarzyszącej mu Strategii Bezpieczeństwa Narodowego (NSS). Podczas publikacji SDSR premier David Cameron zapowiedział, że wydatki militarne zmniejszą się w okresie czterech następnych lat o 8\%, nie spadną jednak poniżej wymaganego przez Sojusz Północnoatlantycki poziomu 2\% Produktu Krajowego Brutto. 
Wobec obniżenia budżetu obronnego o prawie 6 miliardów dolarów, brytyjskie władze musiały podjąć decyzje o wycofaniu części używanego sprzętu, a także zwolnieniu lub przeniesieniu w stan spoczynku części personelu Ministerstwa Obrony (Military Balance, 2012: 81-87). Pomimo, iż podjęcie decyzji wynikających z konieczności poszukiwania oszczędności było oczywiste na długo przed ostateczną publikacją efektów przeglądu obronnego, skala zmian i ograniczeń, a także niektóre wybory rządu Davida Camerona okazały się dość zaskakujące.

Decyzją, która ukazuje jak dotkliwe są cięcia w brytyjskiej armii jest znaczna redukcja liczby żołnierzy w poszczególnych rodzajach sił zbrojnych. Do roku 2015 całkowita liczba żołnierzy brytyjskich zmniejszy się przynajmniej o 17 tysięcy: wojska lądowe zostaną zredukowane o 7 tysięcy, natomiast Królewska Marynarka Wojenna (Royal Navy) i Królewskie Siły Powietrzne $(R A F)$ po 5 tysięcy (SDSR, 2010: 32). Co więcej, zwolnienia dotyczą nie tylko zawodowych wojskowych, ale również personelu cywilnego - do 2015 roku pracę straci aż 25 tysięcy spośród 85 tysięcy pracowników zatrudnionych w Ministerstwie Obrony. Według jednego z najbardziej cenionych brytyjskich znawców problematyki bezpieczeństwa prof. Malcolma Chalmersa nie można również wykluczyć, że na okres do 2020 roku zostały już zaplanowane kolejne redukcje obejmujące kolejne 7 tysięcy etatów cywilnych, a także dodatkowe zwolnienia w marynarce wojennej i lotnictwie. Tak daleko idące decyzje brytyjskiego rządu budzą pewne wątpliwości, gdyż obniżenie stanu liczbowego personelu wojskowego aż o $15-20 \%$ oraz cywilnego o niemal $40 \%$ może w przyszłości negatywnie wpłynąć na całokształt zdolności obronnych Wielkiej Brytanii (Chalmers, 2011: 19).

Drugim źródłem oszczędności wykorzystanym przez władze brytyjskie jest wycofanie z użytkowania niektórych modeli uzbrojenia. Szczególnie zaskakującą i kontrowersyjną decyzją okazało się wycofanie myśliwców krótkiego startu i pionowego lądowania (Short Take Off and Vertical Landing - STOVL) Harrier GR7/GR9. Samolot Harrier stał się symbolem Królewskich Sił Powietrznych, ikoną zwycięskiej wojny o Falklandy z 1982 roku, a także dowodem zaawansowania brytyjskiej myśli technicznej, co zapewniło mu wyjątkowe miejsce w świadomości Brytyjczyków. Premier David Cameron uzasadniając decyzję o wycofaniu tych legendarnych brytyjskich konstrukcji stwierdził, że wojskowi doradzali mu zachowanie w służbie myśliwców Tornado GR4, dysponujące większymi możliwościami bojowymi, zasięgiem i udźwigiem (Głowacki, 2011). Co ciekawe, brytyjskie władze długo rozważały także możliwość wycofania części myśliwców Tornado i Eurofighter Typhoon, co z wojskowego punku widzenia byłoby kolejnym ogromnym osłabieniem potencjału lotniczego Zjednoczonego Królestwa. Kluczowa rola, jaką ataki z powietrza odegrały podczas kampa- 
nii libijskiej w 2011 roku spowodowała jednak, że taka możliwość została odrzucona.

Kolejną z symbolicznych decyzji podjętych przez koalicyjny rząd w październiku 2010 roku jest wycofanie ze służby ze skutkiem natychmiastowym dotychczasowego okrętu flagowego Królewskiej Marynarki Wojennej lotniskowca Ark Royal. Będący jednym z trzech brytyjskich lotniskowców klasy Invincible, HMS Ark Royal wszedł do służby w 1985 roku i był zaliczany do tzw. lekkich lotniskowców przeznaczonych przede wszystkim dla samolotów krótkiego i pionowego startu oraz śmigłowców. Wycofanie ze służby myśliwców uderzeniowych Harrier spowodowało, że wartość bojowa brytyjskich lotniskowców byłaby niewielka, gdyż jednostki te są zbyt małe by móc obsługiwać samoloty startujące i lądujące w sposób klasyczny. Choć rząd brytyjski przywrócił niedawno do służby Illustrious (trzeci z lotniskowców klasy Invincible), to wobec rezygnacji z Harrierów pełni on jedynie rolę śmigłowcowca. Zakończenie eksploatacji Ark Royal zamknęło więc na okres kilku lat trwający nieprzerwanie od 1924 roku okres panowania brytyjskich lotniskowców. Warto zauważyć, że rezygnacja z używania jednostek klasy Invincible, a także będących ich skrzydłem lotniczym myśliwców pokładowych Harrier oznacza, że do czasu wprowadzenia nowych modeli obu rodzajów uzbrojenia, Wielka Brytania pozbawiła się zdolności uderzenia lotniczego z pokładu lotniskowca (ang. Carrier Strike Capability).

Za równie niespodziewaną decyzję brytyjskiego rządu uznano przerwanie procesu modernizacji morskich samolotów zwiadowczych i zwalczania okrętów podwodnych Nimrod. Pomimo, iż brytyjscy lotnicy testujący samolot Nimrod MRA4 ocenili go bardzo pozytywnie, a proces jego wprowadzania był niemal zakończony, władze zdecydowały się na całkowite anulowanie programu, dzięki czemu w ciągu 10 lat ministerstwo obrony będzie mogło zaoszczędzić 2 miliardy funtów. Rezygnacja z samolotów Nimrod bez wątpienia znacząco obniżyła tzw. zdolności ASW (Anti-Submarine Warfare - Zwalczanie Okrętów Podwodnych) Zjednoczonego Królestwa, co może stanowić zagrożenie zwłaszcza dla okrętów podwodnych klasy Vanguard przenoszących pociski balistyczne z głowicami jądrowymi (Willett, 2011). Inną decyzją, którą należało uznać za nieoczekiwaną jest wycofanie samolotów zwiadu elektronicznego Sentinel R1 zaplanowane na rok 2015, związane $\mathrm{z}$ przekonaniem brytyjskiego rządu, że po zakończeniu operacji w Afganistanie nie będą one nadal potrzebne. Decyzja ta była tym bardziej zaskakująca, jeśli wziąć pod uwagę, że na samoloty Senitel wydano 860 milionów funtów, ostatnia $\mathrm{z}$ jednostek została dostarczona zaledwie w 2009 roku, a na wprowadzenie mających je zastąpić samoloty bezzałogowe Brytyjczykom brakuje funduszy. Doskonałe rezultaty jakie maszyny Sentinel R1 osiągnęły nad Afganistanem, Libią, a także wspierając wojska 
francuskie w Mali, poparte pozytywnymi opiniami przedstawicieli armii spowodowały jednak, że dość realna wydaje się anulowanie decyzji zapisanej w SDSR i pozostawienie samolotów w służbie także po 2015 roku (Donaldson \& Wall, 2013).

Analiza powyższych decyzji sprawia wrażenie, że rząd Davida Camerona stojąc $\mathrm{w}$ obliczu konieczności redukcji deficytu budżetowego Ministerstwa Obrony w zbyt dużym stopniu skupił się na uwarunkowaniach ekonomicznych, mniejszą wagę przywiązując do kwestii efektywności brytyjskich sił zbrojnych. Z drugiej strony, za cenę tymczasowego obniżenia potencjału wojskowego Zjednoczonego Królestwa, budżet obronny Wielkiej Brytanii po raz pierwszy od dziesięcioleci został zbalansowany, o czym poinformował w lutym 2012 roku minister Philip Hammond (Harding, 2012). Warto również podkreślić, że pomimo problemów finansowych, z którymi musiały zmierzyć się władze brytyjskie, nie zrezygnowano z kontynuacji największych przedsięwzięć zbrojeniowych rozpoczętych jeszcze przez Partię Pracy.

\section{Przyszły kształt sił zbrojnych Zjednoczonego Królestwa}

Jednym z zarzutów stawianych przez ekspertów Strategicznemu Przeglądowi Obrony i Bezpieczeństwa jest brak precyzyjnego określenia czy w przyszłości Wielka Brytania zdecyduje się na rozwój swojej strategii militarnej w kierunku morskim, czy też lądowym. Należy pamiętać, że przejmowanie zwiększonej odpowiedzialności za bezpieczeństwo międzynarodowe, a także globalne interesy wymagają od Zjednoczonego Królestwa zdolności do oddziaływania politycznego i militarnego nawet $\mathrm{w}$ regionach znacznie oddalonych od Wysp Brytyjskich. Co więcej, biorąc pod uwagę niewielkie prawdopodobieństwo konfliktu zbrojnego $\mathrm{w}$ najbliższym otoczeniu politycznym, a także specyfikę najpoważniejszych zagrożeń w XXI wieku, wydaje się że z punktu widzenia bezpieczeństwa Zjednoczonego Królestwa priorytetowego znaczenia nabrały zdolności ekspedycyjne.

Dotychczasowa polityka gabinetu Davida Camerona dobrze wpisuje się w trwający od kilkunastu lat proces nadawania brytyjskim siłom zbrojnym ewidentnie ekspedycyjnego charakteru. Choć część decyzji podjętych po przeprowadzeniu przeglądu obronnego można uznać za czasowe osłabienie zdolności ekspedycyjnych brytyjskich sił zbrojny, to należy zaznaczyć, że polityka władz brytyjskich ukierunkowana jest przede wszystkim na efekt długookresowy. Wynika to $\mathrm{z}$ wieloletniego charakteru dwóch najważniejszych inwestycji, których ukończenie znacząco zwiększy możliwości oddziaływania militarnego Wielkiej Brytanii z dala od własnego terytorium. Najważniejszymi brytyjskimi programami zbrojeniowymi obecnej dekady 
jest budowa dwóch lotniskowców uderzeniowych klasy Queen Elizabeth oraz współudział w programie myśliwca wielozadaniowego piątej generacji F-35 (JSF - Joint Strike Fighter). Obie inwestycje mają być swoistą „przepustką" w XXI wiek i stanowić podstawę brytyjskich sił zbrojnych kilkadziesiąt lat. Warto zwrócić uwagę na wzajemnie uzupełniający charakter obu programów: lotniskowiec bez skrzydła lotniczego miałby niewielką wartość bojową, natomiast samoloty wielozadaniowe startujące z pokładów okrętu zyskują możliwość przeprowadzenia nalotu niemal w każdym miejscu na świecie.

Wprowadzenie do czynnej służby lotniskowców oraz myśliwców spowoduje, że Wielka Brytania odzyska kluczową z punktu widzenia potencjału ekspedycyjnego zdolność Carrier Strike Capability, utraconą po wycofaniu lotniskowców klasy Invincible oraz myśliwców Harrier. Rozmiar i skomplikowany charakter obu programów powoduje jednak, że na dzień dzisiejszy trudno przewidzieć datę ich zakończenia, niemniej niewykluczone, że nastąpi to dopiero na początku następnej dekady. Określenie przybliżonej daty zakończenia a także końcowego kształtu inwestycji jest dodatkowo utrudnione ze względu na niekonsekwentną postawę odnośnie wariantów obu rodzajów uzbrojenia. Patrząc przez pryzmat kompatybilności obu rodzajów uzbrojenia, podstawową kwestią jest wybór systemu startu i przyjmowania samolotów, w który będą wyposażone brytyjskie lotniskowce. Decyzja ta ma fundamentalne znaczenie, gdyż wybór danego systemu pociąga za sobą konieczność zamówienia odpowiednio przystosowanego wariantu myśliwca Joint Strike Fighter. Kiedy w lecie 2008 roku, laburzystowski rząd Gordona Browna podpisał kontrakt na budowę lotniskowców, obie jednostki planowano przystosować do przenoszenia samolotów krótkiego startu i pionowego lądowania (Short Take Off and Vertical Landing - STOVL).Według ówczesnych planów w skład skrzydła lotniczego lotniskowców miały wejść myśliwce F-35B (wariant STOVL), a także Harriery. Po przejęciu władzy, gabinet Davida Camerona uznał jednak, że o wiele bardziej korzystna będzie adaptacja nowych lotniskowców do obsługi samolotów startujących w sposób konwencjonalny. Za takim rozwiązaniem przemawiało kilka argumentów. Po pierwsze, myśliwce startujące tradycyjnie mają większy zasięg operacyjny i udźwig niż maszyny wersji STOVL. Po drugie, wydatki związane z zakupem i eksploatacją samolotów konwencjonalnych miały być znacznie niższe niż w przypadku maszyn krótkiego startu i pionowego lądowania (Willett, 2012). Po trzecie, takie rozwiązanie umożliwiłoby realizację jednego $\mathrm{z}$ zapisów traktatu o współpracy obronnej z Francją, przewidującego wspólne wykorzystywanie lotniskowców począwszy od 2020 roku (UK -France Summit 2010 Declaration on Defence and Security Co-operation, 2010). Dlatego też, w październiku 2010 roku podjęto decyzję o zmianie wersji myśliwca, jaki 
zamówiła Wielka Brytania na przystosowany do startu konwencjonalnego F-35C, a także o wyposażeniu brytyjskich lotniskowców w system umożliwiający samolotom start z katapulty i lądowanie za pomocą aerofiniszera (CATOBAR), analogiczny do wykorzystywanego na francuskim lotniskowcu Charles de Gaulle (SDSR, 2010:23). Choć takie rozwiązanie było bardziej korzystne z punktu widzenia przydatności operacyjnej oraz ewentualnej współpracy z sojusznikami, w dobie kryzysu finansowego najważniejszą determinantą dla władz brytyjskich okazał się czynnik ekonomiczny. Świadczy o tym decyzja podjęta przez obradującą pod przewodnictwem premiera Davida Camerona Radę Bezpieczeństwa Narodowego (NSC) w dniu 8 maja 2012 roku, o rezygnacji się z planów przewidzianych w SDSR i powrocie do pierwotnej koncepcji zakładającej adaptację jednostek klasy Queen Elizabeth do obsługi samolotów krótkiego startu i pionowego lądowania a także zakup myśliwca wielozadaniowego wersji STOVL - F-35B (Hopkins \& Norton-Taylor, 2012). Powrót do planu z 2008 roku wynikał z olbrzymiego kosztu (ok. 5 miliardów funtów), jaki na tym etapie budowy pociągnęłaby za sobą rekonstrukcja obu lotniskowców oraz wyposażenie ich w system CATOBAR. W maju 2012 roku, minister obrony Philip Hammond przyznał, że podczas publikacji Strategicznego Przeglądu Obrony i Bezpieczeństwa szacowano, że koszt takiej konwersji będzie o połowę niższy. Ponadto, przystosowanie lotniskowców do przyjmowania samolotów startujących w sposób konwencjonalny opróżniłoby cały program o kolejne trzy lata, co oznaczałoby, że pierwsza z jednostek weszłaby do służby nie wcześniej niż w 2023 roku (Carrier Strike: The 2012 Reversion Decision, 2012).

Niekonsekwentne stanowisko rządu Zjednoczonego Królestwa w sprawie lotniskowców uderzeniowych oraz myśliwców piątej generacji z pewnością obniża jego wiarygodność w oczach obywateli oraz sojuszników, a także dodatkowo utrudnia próbę prognozowania, jak ostatecznie będzie wyglądał trzon brytyjskich sił zbrojnych na początku kolejnej dekady. Decydujący wpływ uwarunkowań ekonomicznych „wiążących ręce” rządowi Zjednoczonego Królestwa w zakresie polityki obronnej potęguje wrażenie swoistego braku jednolitej wizji konstrukcyjno-strategicznej brytyjskich władz. Warto zaznaczyć, że na obecnym etapie, niemożliwe jest nawet określenie liczby lotniskowców, które w przyszłości wejdą do czynnej służby w Królewskiej Marynarce Wojennej. W Strategicznym Przeglądzie Obrony i Bezpieczeństwa zapisano, że Wielka Brytania potrzebuje jednej jednostki, gdyż jest mało prawdopodobne by sytuacja międzynarodowa wymagała użycia sił większych niż pojedyncza grupa lotniskowcowa. Konieczność poszukiwania oszczędności stawia również pod znakiem zapytania finalizację budowy obu jednostek. Względnie prawdopodobnym scenariuszem wydaje się wykorzystywanie operacyjne tylko jednej z nich, 
podczas gdy druga zostanie nie w pełni wyposażona i najprawdopodobniej zakonserwowana. Biorąc pod uwagę niedawną decyzję o rezygnacji z kosztownego przystosowania jednostek klasy Queen Elizabeth do obsługi samolotów startu konwencjonalnego, nie można jednak wykluczyć, że rząd brytyjski zdecyduje się na wykorzystywanie operacyjne również drugiej jednostki, zwłaszcza, że utrzymywanie jej w przewidzianej przez SDSR „zwiększonej gotowości” (extended readiness) będzie i tak kosztować ok. 15 milionów funtów rocznie.

Równie skomplikowana wydaje się sytuacja związana z przyszłym zakupem samolotów wielozadaniowych Joint Combat Aircraft ${ }^{2}$. 0 ile wydaje się, że decyzja o zakupie myśliwca F-35 w wersji przystosowanej do krótkiego startu i pionowego lądowania jest ostateczna, to na dzień dzisiejszy trudno przewidywać liczbę maszyn zakupionych finalnie przez Wielką Brytanię. Podobnie jak w przypadku lotniskowców klasy Queen Elizabeth, najważniejszą determinantą będą bez wątpienia kwestie finansowe. Warto podkreślić, że koszt całego programu Joint Combat Aircraft będzie o wiele wyższy niż przewidywano w 2001 roku, kiedy ówczesne władze brytyjskie potwierdzały swoje zamówienie. Zakładano wówczas, że pojedynczy myśliwiec F-35 będzie kosztował 35-40 milionów dolarów, jednak wraz z rozwojem projektu przewidywana cena systematycznie rosła. Choć na obecnym etapie ostateczny koszt jednostkowy samolotu jest trudny do przewidzenia, niewykluczone, że będzie on nawet trzykrotnie wyższy niż początkowo przewidywano i znacznie przekroczy kwotę 100 milionów dolarów, co zmusza brytyjskie władze do zmniejszenia zamówienia. Po publikacji Strategicznego Przeglądu Obrony i Bezpieczeństwa stało się jasne, że do brytyjskich sił zbrojnych trafi znacznie mniej maszyn, niż zakładano w 2001 roku, kiedy Brytyjczycy złożyli zamówienie na 138 samolotów. Nie określono jednak dokładnej liczby zakupionych samolotów, a jedynym fragmentem dokumentu poruszającym tę kwestię był zapis mówiący, że grupa lotnicza lotniskowca klasy Queen Elizabeth będzie składała się z jedynie 12 samolotów F-35, podczas gdy wcześniejsze założenia przewidywały stacjonowanie 36 myśliwców na każdej z tych jednostek (SDSR, 2010: 23). Pomimo iż od publikacji SDSR minęły trzy lata, brytyjskie władze wciąż nie sprecyzowały liczby zakupionych w przyszłości myśliwców. W lipcu 2012 roku minister Hammond podczas swojego pobytu w Stanach Zjednoczonych poinformował jedynie, że Wielka Brytania zakupi na pewno co najmniej 48 samolotów F-35B (Brooke-Holland, 2013: 6). Ostateczne

2 Program Joint Strike Fighter (JSF) rozpoczął się w 1996 roku. Brytyjskie Ministerstwo Obrony oraz amerykański Departament Obrony w dniu 17 stycznia 2001 Memorandum of Understanding, na mocy którego Zjednoczone Królestwo uzyskało pełny dostęp do programu, który w części przeznaczonej dla Brytyjczyków przemianowano na Joint Combat Aircraft - JCA 
decyzje dotyczące zarówno liczby zamówionych myśliwców wielozadaniowych jak i wykorzystywanych operacyjnie lotniskowców uderzeniowych zostanie potwierdzona najprawdopodobniej dopiero po przeprowadzeniu kolejnego przeglądu obronnego, który ma zostać opublikowany po wyborach parlamentarnych w 2015 roku (Jones, 2012).

Wspomniane powyżej dylematy przed jakimi stanęły brytyjskie władze mają fundamentalne znaczenie dla przyszłości brytyjskich sił zbrojnych. Należy pamiętać, że lotniskowce uderzeniowe oraz myśliwce wielozadaniowe będą przez kilkadziesiąt lat stanowić o zdolnościach wojskowych Zjednoczonego Królestwa. Odsunięcie w czasie kluczowych decyzji na okres po następnych wyborach parlamentarnych uwarunkowane jest przede wszystkim trudną do przewidzenia sytuacją finansową ministerstwa obrony. Warto zaznaczyć, że następny gabinet, wyłoniony w wyborach parlamentarnych w 2015 roku będzie zmuszony do ostatecznego rozstrzygnięcia wspomnianych kwestii, gdyż pod koniec kolejnej kadencji oba programy zbrojeniowy będą zbliżać się do finalizacji (Antill \& Ito, 2012).

Choć gabinet Davida Camerona zdecydował się na przesunięcie momentu podjęcia kluczowych decyzji o kilka lat, to podjął również kilka rozstrzygnięć „mniejszego kalibru” istotnych z punktu widzenia rozwoju potencjału morsko-ekspedycyjnego Wielkiej Brytanii. Doskonałym przykładem jest program okrętów podwodnych o napędzie jądrowym klasy Astute przeznaczonych do wykonywania szerokiego zakresu misji, w tym przede wszystkim zwalczania wrogich jednostek pływających (w terminologii NATO takie jednostki określa się symbolem SSN - Submersible Ship Nuclear). Władze brytyjskie zdecydowały się nie tylko na wyłączenie wspomnianej inwestycji z programu cięć budżetu obronnego, lecz również na jej rozszerzenie poprzez zamówienie wcześniej nie zaplanowanej, siódmej jednostki - HMS Ajax, o czym w dniu 11 grudnia 2012 roku poinformował minister obrony (BAE Systems Secures \$ 1.92 Bln Submarine Deal, 2012).

Kolejną inicjatywą, którą Wielka Brytania zdecydowała się kontynuować pomimo kłopotów finansowych jest program niszczyciela rakietowego typu 45 (Daring), będącego nie licząc lotniskowców największą brytyjską jednostką morską w ostatnim półwieczu (Nałęcz, 2010). Wyposażone w najnowsze rozwiązania technologiczne niszczyciele klasy 45 są następcą wysłużonych jednostek klasy 42 (Sheffield) uczestniczących jeszcze w wojnie z Argentyną o Falklandy. Choć programu nie ominęły poważne problemy finansowe, które opóźniły jego finalizację o ok. 3 lata, ostatni z sześciu zamówionych w 2000 roku niszczycieli wszedł do służby 26 września 2013 roku („Destroyer HMS Duncan 'Christened'”, 2013).

Z punktu widzenia zdolności ekspedycyjnych brytyjskich sił zbrojnych niezwykle istotnym jest również zapis Strategicznego Przeglądu Obrony i Bezpieczeństwa dotyczący dalszego funkcjonowania tzw. Stałych Baz 
Operacyjnych (PJOB - Pernament Joint Operating Base), które znajdują się obecnie na Gibraltarze, Cyprze, Falklandach oraz na atolu Diego Garcia na Oceanie Indyjskim (SDSR, 2010: 28). Dzięki wspomnianym bazom, Wielka Brytania ma możliwość rozmieszczenia własnych jednostek również z dala od własnego terytorium, a także zapewnienia im odpowiedniego zaplecza logistycznego i technicznego. Przykładem wymiernej korzyści wynikającej z posiadania bazy w terytorium zamorskim było wykorzystanie atolu Diego Garcia przez wojska brytyjskie i amerykańskie podczas wojny w Afganistanie w 2001 roku oraz w czasie obu wojen w Iraku.

\section{Przyszłość brytyjskiego odstraszania jądrowego}

Kolejnym z kluczowych obszarów polityki obronnej Zjednoczonego Królestwa, którym obecne władze brytyjskie poświęcają wiele uwagi jest odstraszanie jądrowe. $\mathrm{W}$ ciągu kilku lat Wielka Brytania będzie bowiem zmuszona do podjęcia strategicznych decyzji związanych z własnymi siłami jądrowymi. Taka konieczność związana jest ze zbliżającym się do końca okresem użytkowania okrętów podwodnych klasy Vanguard, które przenoszą pociski Trident $\mathrm{z}$ głowicami atomowymi i stanowią obecnie jedyny instrument brytyjskiego odstraszania jądrowego (Jaźwiński, 2005: 13). Okres użytkowania wspomnianych okrętów podwodnych ustalono początkowo na 25 lat, co oznacza, że najstarsza spośród czterech jednostek - HMS Vanguard pozostająca w służbie od 1994 roku powinna zostać wycofana około roku 2019, natomiast najnowsza - HMS Vengeance siedem lat później. Biorąc pod uwagę długi okres projektowania i budowy okrętów podwodnych o napędzie jądrowym, władze brytyjskie powinny podjąć kluczowe rozstrzygnięcia w tym zakresie już teraz (Clarke, 2004: 54).

Warto zaznaczyć, że podczas trwającej od kilku lat debaty dotyczącej zastępstwa dla systemu Trident, coraz częściej pojawiały się głosy kwestionujące zasadność zachowania przez Wielką Brytanię zdolności odstraszania nuklearnego. Głównym argumentem przeciw brytyjskiej broni atomowej są ogromne koszty jej utrzymania, które wynoszą około 2 miliardów funtów rocznie. Co więcej, program zastąpienia jednostek Vanguard nową generacją okrętów podwodnych będzie najprawdopodobniej najdroższą inwestycją zbrojeniową $\mathrm{w}$ historii brytyjskich sił zbrojnych. Choć na dzień dzisiejszy trudno precyzyjnie określić koszt budowy flotylli strategicznych okrętów podwodnych nowego typu, to niewątpliwie znacznie przekroczy on kwotę 25 miliardów funtów (The United Kingdom's Future Nuclear Deterrent: The Submarine Initial Gate Parliamentary Report, 2011: 10). Oznacza to, że sam program odstraszania nuklearnego pochłonie około 
25\% wszystkich środków finansowych przeznaczonych na modernizację brytyjskiego uzbrojenia w latach 2012-2022.

Posiadanie sił jądrowych przez Zjednoczone Królestwo jest jednak trudne do uzasadnienia nie tylko z powodu olbrzymich kosztów jej utrzymania, ale również ze względu na kilka argumentów natury politycznej i społecznej. Po pierwsze, na Wyspach Brytyjskich nierzadko pojawiają się opinię mówiące, że należy zrezygnować z posiadania broni atomowej gdyż specyfika post-zimnowojennego środowiska międzynarodowego powoduje, że prawdopodobieństwo konieczności użycia sił jądrowych jest znikome. Przeciwnicy broni atomowej podkreślają np., że pociski wyposażone w głowice jądrowe są całkowicie bezużyteczne wobec terroryzmu międzynarodowego będącego najpoważniejszym zagrożeniem XXI, oraz innych wyzwań związanych z działalnością podmiotów niepaństwowych (Jenkins, 2010). Po drugie, niektórzy eksperci uważają, że brytyjski arsenał nuklearny liczący obecnie ok. 120 głowic jądrowych jest zbyt mały by stanowić zagrożenie dla któregokolwiek z potencjalnych wrogów dysponujących bronią atomową - Chin, Rosji czy Iranu. Wreszcie po trzecie, w brytyjskiej debacie publicznej powstał swoisty front złożony z przedstawicieli różnych środowisk otwarcie krytykujących posiadanie przez Zjednoczone Królestwo broni jądrowej. Oprócz tradycyjnie nieprzychylnej Kampani na rzecz Rozbrojenia Nuklearnego (CND - Campaign for Nuclear Disarmament), można $\mathrm{w}$ tym miejscu wskazać m.in. hierarchów kościelnych $\mathrm{z}$ arcybiskupem Cantenbury Rowanem Williamsem na czele, czy też niektóre partie polityczne takie jak wchodzący w skład koalicji rządzącej Liberalni Demokraci, walijska Plaid Cymru, Partia Zielonych Anglii i Walii czy Szkocka Partia Narodowa, uznające, iż lepszym rozwiązaniem okazałoby się przeznaczenie funduszy na uzbrojenie konwencjonalne („Trident Missile Costs 'Immoral,'” 2006).

Perspektywa ogromnych wydatków w zestawieniu z koniecznością poszukiwania oszczędności powodują, że działania brytyjskich władz w zakresie odstraszania jądrowego są obecnie determinowane w głównej mierze właśnie przez kwestie finansowe. Świadczy o tym, przełożenie momentu podjęcia „kluczowych decyzji” dotyczących przyszłości odstraszania jądrowego na rok 2016. Takie rozwiązanie uargumentowano wynikającą z niego możliwością zaoszczędzenia przez brytyjskie ministerstwo obrony 750 milionów funtów w latach 2011-2015 (Watt, 2011). Odsunięcie w czasie wspomnianych decyzji oznacza również opóźnienie ewentualnego rozpoczęcia programu budowy nowych okrętów podwodnych, czego skutkiem będzie wejście pierwszej z jednostek do służby później niż pierwotnie planowano. $Z$ tego powodu, gabinet Davida Camerona zdecydował o przedłużeniu o 5 lat okresu użytkowania każdego z obecnie używanych okrętów klasy Vanguard. Zgodnie z zapisami rządowego dokumentu Przyszłość Odstraszania Jądrowego Zjednoczonego Królestwa, w roku 2028 kiedy 
najprawdopodobniej ukończony zostanie pierwszy z nowych okrętów podwodnych, w służbie pozostaną nadal dwie „najmłodsze” jednostki klasy Vanguard. Wydaje się, że dzięki takiemu rozwiązaniu przejście pomiędzy dwiema generacjami strategicznych okrętów podwodnych zostanie przeprowadzone bez większego uszczerbku dla brytyjskiego odstraszania jądrowego (The Future of the United Kingdom Nuclear Deterrent, 2006: 9).

Warto zaznaczyć, że budowa nowej generacji okrętów podwodnych, którą konsekwentnie popiera Partia Konserwatywna, od lat wzbudza dużo kontrowersji. Co ciekawe, pierwotny plan stworzenia następcy systemu Trident został opracowany jeszcze w czasie sprawowania władzy przez laburzystów. Podczas głosowania w Izbie Gmin w dniu 14 marca 2007 roku, 95 posłów Partii Pracy sprzeciwiło się wspomnianemu projektowi, który został ostatecznie przyjęty jedynie dzięki poparciu pozostających wówczas w opozycji konserwatystów ("Trident Plan Wins Commons Support," 2007). Po wyborach parlamentarnych w 2010 roku, przyszłość odstraszania jądrowego stała się natomiast polem konfliktu pomiędzy politykami partii tworzących koalicyjny rząd. W listopadzie 2012 roku doszło do otwartego sporu pomiędzy konserwatywnym ministrem obrony Philipem Hammondem, a liderem Liberalnych Demokratów Nickiem Cleggiem pełniącym funkcję wicepremiera. Przyczyną sporu było przeznaczenie dodatkowych funduszy na program projektowania nowej generacji okrętów podwodnych, które było sprzeczne z ustaleniami koalicyjnymi przewidującymi przesunięcie „kluczowych decyzji” na rok 2016 (Wintour, 2012). Warto nadmienić, że liberałowie twierdzą, iż oparcie odstraszania jądrowego na flotylli strategicznych okrętów podwodnych nowej generacji jest zbyt kosztowne, dlatego też optują za alternatywnymi rozwiązaniami takimi jak wyposażenie obecnie używanych jednostek Vanguard w rakiety krótkiego zasięgu lub wykorzystanie pocisków odpalanych z powietrza. Choć Partia Konserwatywna zdecydowanie odrzuca wspomniane możliwości, nie można wykluczyć, że w przypadku ewentualnej zmiany partii rządzącej po wyborach parlamentarnych w 2015 roku, plany dotyczące przyszłości brytyjskiego odstraszania jądrowego zostaną zredefiniowane (Gogowski, 2013).

Można jednak zaryzykować twierdzenie, że osią ewentualnej debaty w brytyjskich kręgach politycznych nie będzie kwestia posiadania broni atomowej, a jedynie przyszły kształt brytyjskich sił jądrowych. Niezależnie od wszelkich głosów sprzeciwu, prawdopodobieństwo, że Zjednoczone Królestwo zdecyduje zrezygnować z zachowania arsenału atomowego wydaje się bowiem być równe zeru. Z punktu widzenia Wielkiej Brytanii, w przypadku sił jądrowych, znacznie ważniejszy od aspektów ekonomicznego i obronnego wydaje się aspekt psychologiczny. Posiadanie broni nuklearnej stanowi dla Brytyjczyków powód do dumy oraz materialny symbol brytyjskiej mocarstwowości i zaawansowania technologicznego, tym cenniejszy gdyż osiągnięty własnymi siłami. 


\section{Konkluzje}

Dzięki przeprowadzonej w niniejszym szkicu analizie najważniejszych problemów decyzyjnych z zakresu polityki obronnej przed jakimi stanęły brytyjskie władze wyłonione w wyborach parlamentarnych 2010 roku, możliwym okazało się wyciągnięcie pewnych wniosków natury ogólnej. Bez mała wszystkie decyzje podjęte dotychczas przez koalicję konserwatywnoliberalną dowodzą, że kluczową determinantą brytyjskiej polityki obronnej jest obecna sytuacja finansowa. Można wręcz zaryzykować twierdzenie, że to właśnie redukcja deficytu budżetu obronnego stała się najważniejszym celem jaki w czasie obecnej kadencji wyznaczył sobie gabinet Davida Camerona. Choć brytyjskim władzom udało się zrealizować ten zamiar, można odnieść wrażenie, że przy podejmowaniu niektórych decyzji zbyt duży nacisk położono na kwestie finansowe, niejako nie doceniając ich negatywnego wpływu na potencjał militarny Zjednoczonego Królestwa. Wycofanie części używanego uzbrojenia spowodowało, że przez kilka najbliższych lat w brytyjskich zdolnościach wojskowych będą istniały swoiste luki, które pozostaną niewypełnione aż do czasu zakończenia długoletnich programów zbrojeniowych.

Należy również podkreślić, że na półmetku kadencji obecnego gabinetu, żaden spośród najważniejszych dla przyszłości brytyjskich sił zbrojnych dylematów nie został definitywnie rozwiązany. Decyzja o przeniesieniu kluczowych rozstrzygnięć na okres po wyborach parlamentarnych w 2015 roku opiera się na optymistycznym założeniu, że sytuacja finansowa nie będzie wówczas ograniczała w tak dużym stopniu jak obecnie pola manewru władz w Londynie. Choć w brytyjskiej debacie publicznej pojawiają się nierzadko nie pozbawione rozsądnej argumentacji głosy zarzucające gabinetowi Davida Camerona niekonsekwencje i brak odpowiedzialności, odłożenie o kilka lat momentu podjęcia tych kluczowych decyzji nie wpłynie w znaczący sposób na opóźnienie finalizacji inwestycji. Moment ukończenia najważniejszych dla Wielkiej Brytanii programów zbrojeniowych, który nastąpi najprawdopodobniej na początku kolejnej dekady, będzie można uznać za symboliczny początek nowej epoki w historii brytyjskich sił zbrojnych. Obecne dziesięciolecie należy natomiast postrzegać jako okres przejściowy, w którym polityka obronna Wielkiej Brytanii jest przygotowywana do swoistego „kroku milowego” w XXI wiek. Brytyjskie władze celowo zdecydowały się na czasowe osłabienie potencjału militarnego Wielkiej Brytanii, gdyż takie rozwiązanie umożliwiło zmniejszenie deficytu sektora obronnego, przy jednoczesnej kontynuacji procesu przystosowywania własnej polityki obronnej do obecnych uwarunkowań. 


\section{Bibliografia}

Antill, Peter D. Ito Pete. The UK and the Joint Strike Fighter: An Acquisition Programme in Crisis? RUSI Defence Systems Analysis. August 18, 2012. (http://www.rusi.org, dostęp 23.11.2012).

"BAE Systems Secures \$ 1.92 Bln Submarine Deal". Navaltoday.com. December 11, 2012. (http://navaltoday.com/2012/12/11/uk-bae-systems-secures-1-92-bln-submarine-deal, dostęp 11.12.2012).

Brooke-Holland, Louisa. The F-35 Lightning II Joint Strike Fighter, UK House of Commons Library Research Papers. April 12, 2013. (http://www.parliament.uk, dostęp 16.04.2013).

Carrier Strike: The 2012 Reversion Decision. Ministry of Defence, National Audit Office, May 10, 2013. (http://www.nao.org.uk, dostęp 11.06.2013).

Chalmers, Malcom. Capability Cost Trends: Implications for the Defence Review. RUSI Working Paper. January 2010. (http://www.rusi.org, dostęp 3.12.2010).

Chalmers, Malcolm. Looking into the Black Hole: Is the UK Defence Budget Crisis Really Over? RUSI Briefing Paper. September 2011. (http://www.rusi.org, dostęp 30.10.2011)

Clarke, Michael. "Does My Bomb Look Big in This? Britain's Nuclear Choices after Trident”. International Affairs No. 80 (2004): 49-62.

Codner, Michael. The British Military Contribution to Operations in Mali: Is This Mission Creep? RUSI Analysis. January 30, 2013. (http://www.rusi.org/, dostęp 2.02.2013)

“Destroyer HMS Duncan 'Christened."' Belfast Telegraph. September 26, 2013. (http:// www.belfasttelegraph.co.uk/news/local-national/northern-ireland/destroyer-hmsduncan-christened-29611382.html, dostęp 28.09.2013)

Donaldson, Kitty, Wall Robert. U.K. Examines Continuing Role for Sentinel Planes. Bloomberg, August 21, 2013. (http://www.bloomberg.com/news/2013-08-21/u-k-examinescontinuing-role-for-sentinel-planes.html, dostęp 21.08.2013)

Czulda, Robert. „Wielka Brytania - Cięcie potęgi”. Nowa Technika Wojskowa No. 2 (2012): 48-56.

Głowacki, Bartosz. „Podzwonne dla Harriera”. Skrzydlata Polska No. 12 (2011): 4-8.

Gogowski, Grzegorz. Torysi, liberałowie, laburzyści a przyszłość brytyjskiego odstraszania jądrowego, Policy Brief, No. 2, 2013. (http://www.pl.britannia.wdinp.uw.edu.pl/, dostęp 01.06.2013).

Gołembski, Franciszek. Polityka zagraniczna Wielkiej Brytanii, Wydawnictwo ASPRA-JR, Warszawa 2001.

Harding, Thomas. "MoD Balances Books First Time in Four Decades, Defence Secretary to Announce". The Telegraph. February 17, 2012. (http://www.telegraph.co.uk/, dostęp 17.02.2012).

Hopkins, Nick, Norton-Taylor Richard. "Government Forced into U-turn on Royal Navy fighter Jets". The Guardian May 10, 2012. (http://www.theguardian.com/uk, dostęp 10.05.2012)

Jadźwiński, Krzysztof. Wielka Brytania jako mocarstwo jądrowe. Warszawa: Askon, 2005.

Jenkins, Simon. "Does Britain Really Need the Military?" The Guardian November 5, 2010. (http://www.theguardian.com/uk, dostęp 19.11.2010)

Jones, Rhys. "Britain Won't Decide on F-35 Fighter Numbers till 2015". Reuters February 7, 2012. (http://uk.reuters.com, dostęp 24.02.2012)

Kirkup, James. "Hillary Clinton's Warning to Britain over Cuts in Defence Budget". The Telegraph, October 14, 2010. (http://www.telegraph.co.uk, dostęp 15.10.2010)

Nałęcz, Maciej. „Przeciwlotnicza tarcza Royal Navy”. Morze, Statki i Okręty No. 10, (2010): 4-14. 
Norton-Taylor, Richard. UK Intervention in Mali is Strategy for Future, Says Defence Secretary, Defence and Security Blog. January 29, 2013, (http://www.theguardian.com/ world/2013/jan/29/uk-intervention-mali-strategy-future, dostęp 29.01.2013)

Seldon, Anthony. Blair's Britain 1997-2007. Cambridge: Cambridge University Press, 2007.

Stockholm International Peace Research Institute. SIPRI Yearbook 2010. Oxford: Oxford University Press, 2010.

Strategic Defence Review, Ministry of Defence, July 1998, (http://webarchive.national archives.gov.uk, dostęp 18.07.2010).

SDSR - Securing Britain in an Age of Uncertainty: The Strategic Defence and Security Review.

The Future of the United Kingdom Nuclear Deterrent. December 2006. (https://www.gov.uk, dostęp 21.11.2011)

The Military Balance 2012. International Institute for Strategic Studies, London, 2012.

The Military Balance 2013. International Institute for Strategic Studies, London, 2013.

The United Kingdom's Future Nuclear Deterrent: The Submarine Initial Gate Parliamentary Report. Ministry of Defence, May 2011. (https://www.gov.uk/, dostęp 21.01.2012).

Trident Missile Costs 'Immoral'. BBC, September 28, 2006, (http://news.bbc.co.uk/2/hi/ uk_news/scotland/5387750.stm, dostęp 19.12.2011).

Trident Plan Wins Commons' Support. BBC, March 15, 2007. (http://news.bbc.co.uk/ 2/hi/uk_news/politics/6448173.stm, dostęp 19.12.2011)

UK-France Summit 2010 Declaration on Defence and Security Co-operation. Prime Minister's Office, 10 Downing Street, November 2, 2010. (https://www.gov.uk, dostęp 23.01.2012).

Warchał, Arnold. Zarys brytyjsko-amerykańskiego partnerstwa politycznego. Era Blaira i Browna. Wybrane problemy polityczne rządów Partii Pracy w Zjednoczonym Królestwie 1997-2010. Red. Przemysław Biskup, Franciszek Gołembski, Małgorzata Kaczorowska, ASPRA, Warszawa 2010.

Watt, Nicholas. "David Cameron to Delay Trident Replacement". The Guardian. October 19, 2011. (http://www.theguardian.com/uk, dostęp 20.10.2011)

Willett, Lee. Mind the Gap: Strategic Risk in the UK's Anti-Submarine Warfare Capability. RUSI Analysis. February 4, 2011. (http://www.rusi.org/, dostęp 2.01.2012)

Cats and Traps: Launching the Carrier Debate in the Right Direction? RUSI Analysis. April 27, 2012, (http://www.rusi.org/, dostęp 30.06.2012)

Wintour, Patrick. "Nick Clegg Attacks Philip Hammond for 'Jumping the Gun' on Trident". The Guardian October 29, 2012. (http://www.theguardian.com/uk, dostęp 30.10.2012).

Wiśniewski, Bartosz. Koncepcja bezpieczeństwa Wielkiej Brytanii. Bezpieczeństwo międzynarodowe po zimnej wojnie. Red. Ryszard Zięba. Warszawa: Wydawnictwa Akademickie i Profesjonalne, 2008.

\section{British Defense Policy Dilemmas after United Kingdom General Election of 2010}

Summary

David Cameron's coalition cabinet, which was formed after the United Kingdom general election of 2010, faced the need to address a number of serious defense policy dilemmas. The biggest challenge was to reduce the huge budget deficit left by the Labour Party in the Ministry of Defense, while maintaining a high level of military capabilities. The main aim of this article is to analyze the efforts taken by the British authorities over the last three 
years to achieve both of these objectives. To this end, the author characterized the main decisions taken by the British Cabinet to reduce defense spending. He also presented the gradually emerging shape of the future British armed forces. The article discusses major weapons investments carried out at present and planned in the future by the United Kingdom. Individual investments are analyzed in terms of their potential relevance for the British armed forces, the costs of completion and the factors that influence the decision to choose a particular variant of the weapon. In the last part of the paper, the British dilemmas with nuclear forces are characterized. 